\title{
MOSER, Antônio; MOSER, Ana Maria. Colhendo Flores entre Espinhos. Ciência e atitudes pessoais garantindo um envelhecimento com qualidade. Petrópolis: Vozes, 2010.
}

João Batista Libanio*

O título e o subtítulo bem expressivos indicam já o clima do livro. As flores são o envelhecimento com qualidade de vida. Os espinhos refletem as agruras para que se atinja tal altura. E o estudo se processa sob vários olhares que o subtítulo traduz: ciência biológica, psicológica, espiritualidade e teologia.

Os autores, tio e sobrinha, ele frei franciscano, moralista de renome, e ela, psicóloga com experiência no campo da geriatria. Ambos bem preparados para oferecem excelentes reflexões.

Os autores encontraram-se diante de um bívio. O campo do envelhecimento implica série enorme de questões. Coube-lhes escolher ou enveredar por uma delas ou oferecer uma visão geral sobre a complexidade do problema. Eles optaram pela segunda via.

O livro não se restringe, pois, a determinado campo, nem só ao aspecto psicológico, ou sociológico, ou espiritual, ou teológico. Não. Apresenta verdadeiro mapeamento de inúmeros objetos de pesquisa. Imaginemos um geógrafo que mapeasse as bacias fluviais do Brasil de tal maneira que contemplaríamos verdadeiro emaranhado de rios. Mas ele mesmo não se aventurou por nenhum rio em particular. Deixou aos futuros estudiosos que escolhessem algum deles e depois o visitassem.

Tais estudos se fazem necessários para evitar simplismos de soluções. Os slogans, as propagandas, os comerciais escondem a bacia fluvial e falam como se houvesse um único rio, aquele que lhes interessa.

\footnotetext{
* Doutor em Teologia (Gregoria-Roma) e professor da FAJE (Faculdade Jesuíta de Filosofia e Teologia). País de origem: Brasil. E-mail: secteologia@faculdadejesuita.edu.br
} 
O objetivo central, que os autores pretendem, ao abordar o tema e os aspectos que o cercam, se resume em batalhar por um processo de envelhecimento com qualidade. Por isso, eles consideram os diferentes campos aí envolvidos a fim de que as pessoas envelheçam de maneira humana e feliz.

Tudo começa com o sonho humano de felicidade, juventude e imortalidade que se confronta com o fato inexorável de sofrimentos, de infelicidades, de perda da juventude pela velhice e de perda da imortalidade pela morte.

Esse sonho tem importância para acordar nas pessoas energias que lhes permitam um caminhar sadio ao longo da vida desde que se supere o aspecto mítico e se alcance a sua verdade e realidade. O livro contrapõe-se à ideologia de cunho comercial que passa subliminarmente a ideia de uma vida, como se não existisse ocaso.

Vêm em auxílio do conhecimento do processo de envelhecimento muitas pesquisas científicas e descobertas tecnológicas. Essas necessitam ser testadas. Algumas já se tornaram realidade. Mostram que se pode melhorar muito tal processo, retardando-o e evitando doenças, deficiências e fragilidades precoces. Outras geram o perigo de criar expectativas falsas e míticas. O sonho da imortalidade biológica pertence ao mito e não às possibilidades da ciência, embora surjam afirmações de cientistas nesse sentido. Visões filosóficas e teológicas completam esses aspectos, dando-lhes compreensão e sentido.

Importa tomar consciência de que a situação no Brasil está a mudar em relação ao aspecto demográfico. Os países desenvolvidos entram em lento processo de envelhecimento. O Brasil vai aos solavancos com envelhecimento acelerado e inesperado. Isso está a requerer outra política social. Pelos dois polos o Brasil envelhece: diminuição da natalidade e prolongamento dos anos de vida das pessoas. A longevidade tem a dupla face de esperança e de preocupação. As pessoas aumentam os anos de vida, mas acomete-selhes a incerteza da qualidade dessa vida prolongada.

A medicina, a psicologia, a geriatria, a gerontologia, reflexões filosóficas e teológicas são solicitadas a empenhar-se a fim de ajudar as pessoas a vivenciarem o processo de envelhecimento de maneira humana, sábia, feliz.

Há questões que visam diretamente à pessoa. Cabe prepará-las, ajudá-las a descobrir em si atitudes sadias e despertar energias espirituais diante do fato inexorável do fluir dos anos. Aqui a psicologia traz enormes colaborações. As pessoas próximas aos anciãos têm 
condições de acordar neles forças positivas. O exercício reflexivo sobre o próprio caminho, certa solidão e silêncio para digerir as vivências passadas, elementos filosóficos e teológicos de esperança propiciam caminhar sereno pelas vias do envelhecimento.

Outros problemas vêm do meio ambiente e cultural em que as pessoas vivem. Interessa estudá-lo e oferecer sugestões para criá-lo o mais propício possível. A cultura do corpo, a mitificação da juventude e outros traços culturais carecem ser interpretados e criticados desde a perspectiva do caminhar dos anos.

Mereceram reflexões as instituições dedicadas ao cuidado dos anciãos, desde a família até aquelas geridas pelo Estado. Faz-se mister um levantamento sério sobre elas e sua qualidade a fim de estabelecer política eficiente e competente para proteger os anciãos. Não se pode esquecer a importância da legislação nesse campo. Sobretudo para as camadas socialmente pobres o país permanece altamente devedor de política séria e eficiente. Há grande defasagem entre programas bem elaborados para a terceira e quarta idade e sua realização prática.

No caso de enviar algum ancião para uma casa de acolhida, os autores trabalham bem a questão: qual instituição, quem comunica a notícia, como preparar o ancião para ela. Esse simples fato implica muitos fatores humanos a serem considerados a fim de evitaremse traumas, depressões profundas e isolamento do ancião.

Numa palavra, o livro considera o caminho pessoal do ancião com suas belezas e riscos, oferecendo sugestões de valorização da sua subjetividade. Analisa o processo existencial do envelhecimento no seu dinamismo, salientando os fatores que o inibem e que o favorecem. Naturalmente a reflexão sobre as marcas da velhice no corpo e na psique tem importante espaço. No passo seguinte, o ambiente social ocupa a atenção, para terminar com o aporte da religião e especialmente da fé na ressurreição.

Como se vê, caminha-se por inúmeras e belas paisagens. O livro ajuda tanto quem está já avançado em anos para compreender o próprio processo e, se preciso for, redimensioná-lo, como quem cuida dos anciãos. Insiste-se muito na competência dos cuidadores e enfermeiros de asilos e casas de acolhida. $\mathrm{O}$ aspecto social, político e econômico mereceu também relevo, cobrando das instituições particulares e sobretudo do Estado política adequada para cuidar dos anciãos. 
Quem se sente nessas duas categorias, já de ancião ou de cuidador por profissão e por condição familiar, tem muito que aprender, ao ler o livro. O público tende a crescer, daí a relevância de que tal tema seja abordado por duas pessoas de séria tradição religiosa e de competência no setor da moral e da psicologia. Boa navegação pelo livro. 